\title{
The Use of E-Learning Using Web-Based Management Introduction In Pamulang University
}

\author{
Ni'mah *, Khaerudin \& Dwi Kusumawardani \\ State University of Jakarta, Jakarta, Indonesia \\ nimahunj@gmail.com \\ *Corresponding Author: nimahunj@gmail.com
}

Received: 27 July 2020

Revised: 13 August 2020

Accepted: 2 September 2020

\begin{abstract}
Web-based e-learning in management introductory courses at Pamulang University, this study discusses studying elearning in subjects at Pamulang University specifically on management introductory courses. This research was conducted at Pamulang University. This research was conducted in March 2020 until July 2020. The research method uses qualitative methods with primary data or secondary data. The results of this study indicate that the use of elearning at Pamulang University has provided benefits for system improvement and for improving the quality of comfort. And e-learning learning has been implemented well by Pamulang University or more focused on management study programs. Because e-learning has become a mandatory part, Pamulang University continues to improve so that its utilization continues to improve. At least some of the things that are unique from this research are the University of Pamulang using e-learning as a whole. All subjects must be scheduled to represent lectures conducted face-to-face. This supports the un pam students to have a closeness with technology.
\end{abstract}

Keywords: utilization; e-learning; introduction to management;

\section{Introduction}

Education is a very important thing for the country. Each country has its challenges in advancing education. Many factors affect the speed of development of education in a country. One such factor is the educational policy which is set as a juridical basis. Regulations on education have a great influence on the development of education. Indonesia as an independent country since 1945 has experienced about ten times the change in the educational curriculum. The purpose of the curriculum change is of course always looking for the best format of the Indonesian education system, because education plays an important role in the development of Indonesia, both economic development or the development of other sectors.

The Indonesian state has its challenges in dealing with drastic global currents. global competition must be accepted and must be faced. One way to deal with it is with a good education system, to produce a generation that is reliable and has great competitiveness. The current condition of Indonesia is experiencing a big challenge, namely facing domestic challenges that can still be felt by the many interesting news spreaders. this problem is often seen in the good news coverage of print media online. This problem lowers Indonesia's productivity level. Another challenge that is no less important is dealing with social situations that are currently divided because of people's habits of disseminating bad news. Another challenge is the democratic behavior of some people who are not good. This can be witnessed in the product of democracy which almost every year a demonstration party is always held. However, the democratic party is not able to produce good leaders. thus it is certain that bad leaders will not produce good regulations either.

When the discussion about regulation has been touched on in the previous discussion that since independence Indonesia has experienced many changes in the education law. However, it seems that until now the law has not yet brought fundamental changes to Indonesian society. The fundamental change is at least in the mindset and way of behaving because the mindset and way of behaving is a picture of Indonesian education. Education in this era has experienced many changes, namely the inclusion of technology in the development of education will further facilitate the educational goals. Lately, technology is developing very rapidly. This development is proven when all people have used technology in all their needs, both from children to adults and from all walks of life. The development of the times requires that all life uses technology so that technology is also needed in the world of education today, used for the learning 
process, and in the management of education.

President of the Republic of Indonesia Joko Widodo often delivers his speeches at formal forums, such as when inaugurating the opening of the Indonesia Industrial summit and launching of making Indonesia 4.0 at JCC Senayan Jakarta that technological developments are currently very rapid and in the era of 4.0 all work will be dominated by robots The President advised that as a society, it must follow the times. Technology in education is needed nowadays. International education is very much related to technology (Setkab, 2019). The development of this technology in the world of Indonesian education is very important, as proof is the existence of learning activities that always involve technology in the learning process. Almost all teachers in schools use technology-based learning media for learning, because technology is considered capable of creating a fun and interesting learning atmosphere.

Learning media as one source of learning has a very close role in the learning process. Learning resources can give people the opportunity to learn with easy access to learners (Gartika et al, 2019; Irfansyah et al, 2020). Learning resources are useful for expanding people's opportunities to learn and can also improve the quality of education. Quality learning resources can improve the process, learning outcomes, and quality of education. Types of learning resources are people, tools, environment, procedures, and mysticism are some of them. Content distributed through e-learning is one source of learning. E-learning is defined as the delivery of learning content or learning experiences in electrochemical using computers and computer-based media (Kimmel, 1995; Mutmainnah et al, 2020; ). E-learning based learning has been utilized by all levels of Education (Molinda, 2005). Currently, state and private universities have implemented lectures that use e-learning systems in their learning activities. One of the universities that have implemented e-learning programs in lectures is Pamulang University. It's a campus with approximately 80 thousand students.

Based on data from the results of e-learning learning at Pamulang University, it has been running for quite some time around 2000, so that Pamulang University has advantages in serving tertiary education. Pamulang University as a private campus has its challenges in implementing e-learning learning, Pamulang University has its advantages in implementing e-learning learning for all subjects. This e-learning becomes an obligation for Pamulang University students and lecturers to do e-learning that has been scheduled by the teaching team. However, Pamulang University is also not optimal in carrying out learning-learning, because of the web-based learning process so that it might be possible to use the services of others in the implementation of e-learning learning. About $65 \%$ of Pamulang University students have worked and do not rule out the possibility of this happening in the implementation of e-learning learning.

One of the courses at Pamulang University that utilizes e-learning is Introduction to Management. The results of interviews with supporting lecturers obtained data that students are less active, tend to be passive in e-learning learning. Learning outcomes using e-learning do not match expectations. Students when they finish learning with e-learning, are asked by lecturers about the topics discussed in e-learning, students cannot answer. it means students don't understand the material. Students learning by e-learning only copy from google references. This condition occurs because there is no supervision. Lecturers only accept reports of e-learning results, but they cannot prove whether the student concerned is doing the e-learning.

The Association of Education Communication \& Technology (AECT, 1994) put forward the definition of instructional technology as follows: "instructional technology is the theory and practice of design, development, utilization, management, and evaluation of processes and resources for learning (Rechey 1994). Based on the above definition Educational Technology is a theory and practice in the design, development, utilization, management, and evaluation of processes and resources for learning. Seeing this concept, the educational technology talks about a practice in learning that involves a technology that is useful for designing learning, development in educational sciences, and used for the use of evaluation of learning. Seeing this concept also shows that education at this time is needed for technology in learning. It is well known that education requires education in learning process activities. Related to this, definition according to Hackbarth (1996), understands this conception that Educational Technology is a multidimensional science concept whose discussion consists of 1) showing that in education involving technology aims to provide problems in solving problems faced by students and instructor; 2) in this case all inviting materials using digitalization, such as modules and books can all be stored digitally; 3 ) a profession consisting of various occupational categories; and 4) that technology cannot be separated from the world of education (Warsita, 2013; Purwanita et al, 2019).

In addition to some of the definitions above, AECT (2008), put forward a concept of Educational Technology is the study and practice ethics to facilitate learning and improve performance by creating, using, and managing appropriate technological processes and resources. Technology is inseparable from the keywords namely study, ethics, practice, facilitation, learning, this definition contains several keywords including study; this usually talks about how technology can coexist with educational process activities; then ethical practice; this relates to how the use of technology continues to advance ethics in its use 3. Learning; 
everything that contains novelty continues to involve learning, including the existence of new technology, certainly results from learning. improvement, technology must lead to the improvement of an ability or a performance of work achievement.5 creation, the technology always leads to creation which will be a goal.6 utilization, the most important existence of technology is how every teacher can utilize technology properly.

Based on the definition of Educational Technology that has been described above is closely related to the discussion of the use of e-learning learning that will be carried out systematic research. If you see from the process and source AECT has three pillars which one of them is utilization. Utilization, in this case, is how the existence of technology can and can be utilized to achieve good and fun learning and learning goals. In this case, also the study to be discussed is certainly more specific to the beneficiaries of online learning in tertiary institutions. Considering lately many educational institutions use e-learning in the learning process. Seeing that technological progress is not misinterpreted in everyday life.

The e-learning learning program created is the impact of technological developments, the rapid development of information and communication technology devices requires the development and innovation in the learning aspects to facilitate and facilitate the learning needs of students, e-learning learning programs are one of the learning programs through the use of technological devices, which is the object of study in this qualitative research.

E-learning can be viewed as an innovative approach for delivering welldesigned, learners-centered, interactive, and facilitated learning environment to anyone, anyplace, anytime by utilizing the attributes and resources of various digital technologies along with other forms of learning materials suited for open, flexible, and distributed learning environment (Khan, 2005; Sukariasih et al, 2019). Soekartawi defines elearning as follows: e-learning is a generic term for all technologically supported learning using an arry of teaching and learning tools as phone bridging, audio and videotapes, teleconferencing, satellite transmissions, adn the more reconnized web-based training or computer aided intruction also commonly referred to as online couses" (Dermawan, 2015)

The following are the characteristics of e-learning (Hartati, 2017) (1) In utilizing technology, it can help students or teachers in communicating and facilitate learning (2) Learning that can utilize excellence (3) By using technology in learning, it can help teachers and students in storing books in the form of digital books (4) Using technology can also help educational institutions in data collection and education administration. According to Rashty in Thomas, e-learning can be organized into three forms or models including (Thomas, 2017), namely (1) Adjunct Model; This model only involves technology in the enrichment context, but learning is still used conventionally (2) Mixed/Blended Model; This model is a model that has decided to share presentations for face to face. In contrast to the Adjunct model which only puts an online delivery system also. Pamulang University uses a Blended Learning model in which $40 \%$ of the learning process is done online. While $60 \%$ of the learning process is done conventionally. Although learning is done online, this e-learning program has been systematically arranged and scheduled, to facilitate the learning process (3) Full Online Model (Fully Online); In this model using online as a whole, where this model relies on technology as a whole in its learning.

\section{Methods}

\subsection{Explaining The Difference Between Training And Education}

The research method used is qualitative. Data collection techniques with interviews conducted to obtain a truth of information, this study conducted interviews with 10 students of management study programs Pamulang University. Furthermore, he also conducted interviews with Pamulang University lecturers who were directly involved in this e-learning process. Then the interview was conducted to the head of the institution which houses e-learning at Pamulang University. This is done by directly observing the elearning process in Pamulang University. It is endless to see first hand the online process. This study was conducted to assist the writer in compiling important documents needed as a form of the report. The process of data analysis based on an interactive model developed by Miles and Huberman (1997) will be showed in Figure 1.

Based on the above opinion that as a key instrument of data collection, researchers carry out reduction, phenomenological and data reduction, and transcendental reduction. The phenomenological reduction is done by researchers to free themselves from subjective assessments of phenomena, not the subjective opinion of researchers. Data reduction is done by freeing themselves from theories, scientific propositions, or traditional doctrines that can pollute the purity of data. On the reduction of researchers looking for the essence of the phenomenon of e-leaning in Pamulang University. 


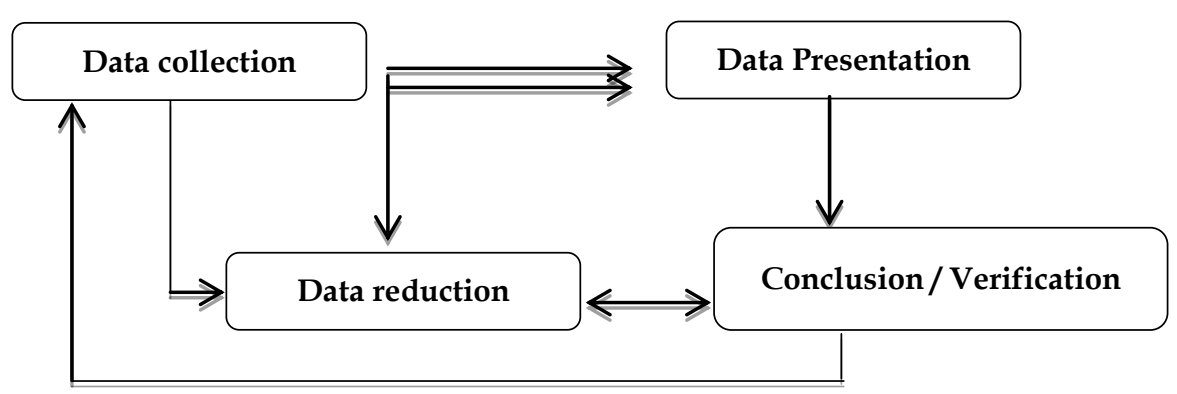

Figure 1. Data Analysis Flowchart

\section{Results and Discussion}

Pamulang University which has a very large number of students has challenges in improving the quality of learning. For this reason, one of the efforts to make Pamulang University unique is the online learning process. Online learning is aimed at creating quality competitive students. Because technology is very close to life, the learning process must also be done online. The current education situation must be able to take advantage of the situation, especially in utilizing online learning. As stated AECT 1997 quoted from Dewi Salma and friends, namely the use of learning resources appropriately to achieve the learning objectives themselves. Utilizers in learning must require an adjustment between learning resources and student conditions so that effective learning processes can be carried out (AECT, 1997).

Pamulang University, in this case, utilizes technology in its learning. Although this is not new in the world of education. Utilizing technology is indeed very good at learning. Pemulang University strives to utilize e-learning as well as possible by always improving the system side of the e-learning web. This is all done to create an excellent online learning atmosphere. This is also said by the Manager of e-learning the learning objectives that we hope for are structured effectiveness in utilizing e-learning media because we only prepare the system and the lecturers who implement it.

In this paper, the researcher only focuses on one course, the introductory course in management. Introduction to management is a basic course in management science which has an important role in students' understanding of management theory. Although Pamulang University also applies this online learning to all courses in the curriculum of management study programs. From the beginning, they observed many things that could be used as research findings. The most interesting thing is when students and lecturer responses have diversity in responding to online learning. Some have a good response, that is to follow really, some don't. Pamulang University has rules on the achievement of creating for teachers and students. If the lecturer wants to be considered present at the discussion meeting then the lecturer must have a record of creating at least 15 responses. This rule is to ensure that e-learning is used as well as possible by lecturers in their learning. Whereas the lecturers should have rules to invite students to work to improve the achievement of creating. This is in line with the lecturer's statement that in Pamulang University the students are diverse because some work and others do not, for that they sometimes come online for the rest of their time, so they are sometimes perfunctory to take part in learning. From the findings above about the use of e-learning, there are still students who have not followed the learning process of e-learning well. This is not in line with the theory of the use of e-learning that should be done online learning. That the principle of learning that is done online is a pleasant thing.

Because online learning does have to prioritize flexibility in the use of time. From the standpoint of time, online learning is certainly certain to have a time-saving side. With this Pamulang University become a campus that supports and participates in utilizing this learning because Pamulang University students and lecturers have very diverse backgrounds lately. Even Pamulang University has a majority of students who are working, so this learning can help students to get educational services. This is in line with what the students said, in my opinion, this online learning helps me, sir, because I'm working, so I feel relaxed and feel helped, it's just that sometimes there are obstacles such as my lack of understanding of the material. From the explanation in the student, it can be explained that the students did feel help from the time side, but could not fully help them in understanding the material being discussed, because not everyone has the same ability in responding to learning, let alone online discussion. Although some feel happy with this online I am happy with this online so I dare to ask questions about the lesson, for me it's one of my uses for me. The media or any way in learning carries risks, not everyone can follow well even though the time can help. This was revealed by their diverse lecturers, not all were responsive in responding, some did not understand some understood quickly, this was the risk of learning online, mas. The principle of online learning must be the same as prioritizing the achievement of learning achievement, this means that lecturers' efforts in improving strategies so that students can have increased motivation in participating in online 
learning must be immediately improved. Lecturers must not be inferior to conditions, lecturers must be able to conquer the state of students, with always the existence of ideas and ways that can help students in learning.

In addition to online learning time, it is very easy in terms of place. Because online learning does not recognize places, anywhere can access. The most important thing is how to use the place to continue participating in online learning. Because Pamulang University has mostly students working, this is an advantage for those who are very busy working. This also means that e-learning helps students in terms of place. This was revealed by students because I work so I'm happy online, I don't need to study.

This expression adds confidence to online learning which is also able to create something that attracts students to participate in learning. Technology is very helpful in learning, although the capital is very expensive by making infrastructure, all of this can help in terms of campus budget expenditure. lecturers and students are greatly benefited by the existence of distant learning because there is no campus activity, the lecturers and students are benefited from the expenditure side, and the campus is also benefited from the other funding sides. This is consistent with the following theory; that the first benefits of online learning are practical. With online learning, the interaction between teachers and students will be more practical because they do not have to travel to meet. Besides, there is no classroom as a place of formal learning. Teaching and learning can take place anywhere as long as it is conducive and can help to focus. Also, there are no additional requirements such as having to "dress up" or "appear formal" so that it is more flexible (Sun Education, 2020).

The internet is indeed very fast when discussing the speed of learning, online can be said to be very fast in terms of the process. This can be seen from the time of its use. E-learning that is done can help lecturers give very fast references in the form of web links, or by giving YouTube access. However, what must be said is that lecturers must have a way so that students can learn management knowledge quickly. In conventional learning, lecturers are very slow in tracing learning resources, but online everything can be found easily. Because all data online can easily be used as a source. This was stated by an introductory lecturer in management. According to the lecturer, this online can help our speed in making the discussion process, he conducted a discussion with case analysis, they can quickly search for cases that he wants to make discussion material according to him very quickly and can also provide sources online can easily, for example, the source of learning is the journal on Google Scholar.

Online education allows lecturers and students to set their own pace of learning, and there is additional flexibility in arranging schedules that fit everyone's agenda. As a result, using an online education platform allows a better work balance and study, so there is no need to give up. Studying online teaches you vital time management skills, which makes finding good work-study balance easier. Having a shared agenda between students and lecturers can also encourage both parties to accept new responsibilities and have more autonomy. The effectiveness of learning can be identified through behaviors, namely learners (lecturers) and students or students who are effective in class, and also most of the environmental context in which the learning process takes place. Learner behaviors are referred to as general behaviors, which include speed, feedback, and example. Unlike teaching in specific strategies, students assume that a high level of teaching is related to the general behavior of the learner (lecturer) used in learning basic skills. Students relatively assume that some general learner behavior (lecturers) is associated with higher-level learning outcomes (tolerance for diverse responses, emphasizing processes rather than products, and opportunities for higherlevel thinking).

On a narrower scope, this online technology network can be seen in the use of online learning in schools or classes. In the online learning environment (Heinich, Molenda, Russell, and Smaldino, 1999) revealed that teachers have more responsibility in making designs. The materials needed by students must be prepared in advance before being presented to be studied by students. Besides, students must understand the objectives (what) that are expected of them regarding the various responses to the stimulus they face. Learning will be more effective if students can be actively involved (Setyayori, 2020). This was also emphasized by the head of the study program who said that our expectations of e-learning were used to the fullest with excitement that this was fun learning, but some still did not realize that this was fun..

Online learning is very effective in time but it still has to deal with psychological aspects that there is a saturation point for someone to use e-learning. With the boredom, the lecturer does not maximize the meeting that should be done well. This was also revealed by the management lecturer. The lecturer sometimes experiences boring points in doing online learning, because sometimes there are conflicts with other work as well, so we do what we are, even though we discuss it again at the next meeting when face to face. From the explanation above, there are still very many lecturers who are not yet total in utilizing this online learning. Yet if viewed from the benefits of online learning is very good and very useful in this digital age. But not everyone has the comfort of learning done online.

Pamulang University has enough experience in implementing e-learning, supported by a system that is 
quite adequate. However, there are still many things that must be considered in terms of usefulness. Especially building a culture of awareness of the importance of online learning. In his explanation, the head of LP3 Pamulang University who happened to be interviewed online also explained that there were still students and lecturers who were lacking in utilizing e-learning. This shows that there are still many LP3 tasks as the person in charge of e-learning so that lecturers have good skills and techniques in implementing good e-learning. Some of the lecturers' arguments also say that sometimes the availability of the system so that online learning can be carried out optimally requires a special system to do that. This was also said by the lecturer: in fact, there must be a joint effort to make online learning useful, there should be a minimum amount of training or a special understanding of how to teach online properly. From this, it can be explained that online learning has been going well, but there are still obstacles to the ability of lecturers to use elearning.

\section{Conclusion}

Based on the focus of the research problem, the results of the research and discussion as well as the research findings, several research conclusions can be explained below that Pamulang University as a tertiary institution has fulfilled the campus criteria in favor of technology in its learning process. And e-learning learning has been implemented well by Pamulang University or more focused on management study programs. Because e-learning has become a compulsory part, Pamulang University continues to strive to improve so that its utilization continues to improve. At least some of the things that are unique from this research are that Pamulang University uses full e-learning, that is, all subjects must be scheduled for lectures that are conducted face-to-face. It aims to make Pamulang University students close to technology. In this elearning learning, Pamulang University has a mature preparation and also has a special institution that is responsible for the running of e-learning learning. Next from the aspect of the effectiveness of e-learning utilization. That there is a continuing lack of awareness in terms of implementation. Nevertheless, Pamulang University's effort to improve the utilization performance is good enough with the policy that lecturers are not allowed to implement it in pragmatic ways. This is followed up which has an impact on the absence of lecturers. Lecturers can be considered to be present when the lecture has reached creat presence at least fifteen times responding to discussions on e-learning. This effort is to cultivate e-learning in the world of education, especially during the current learning process. From the aspect of student responses in doing elearning, it is good enough, because Pamulang University students are very diverse in origin so they are working.

With this distance learning policy students feel fortunate because they do not have to go out of the house just to face-to-face lectures. This is a good response when there is online learning. However, not all feel this way, there are still students who feel less satisfied with the e-learning learning process, ie students feel that not all courses can be done online. For example in the calculation course. Students find it difficult to understand the material. What's more, not all lecturers have the same commitment so that it influences the strategy in utilizing e-learning. In terms of ease of learning basically, learning must be easy, no one feels that learning is difficult. It's just that the hope of technology is an effort to facilitate human affairs or activities. Even so with e-learning, an effort to facilitate students in learning. Because e-learning is done anytime and anywhere, the best thing about e-learning is that it is easy. Although it is found in the field based on research, there are still students who have not found a good point in terms of understanding the material in the process of learning e-learning. Because they feel that sometimes there are lecturers who do not understand the techniques of using e-learning. This technology aspect has approached Pamulang University which also realizes that technology is getting closer to human life. For this existence of the system, Pamulang University also participates in preparing a generation of the technology-capable nation. It really must be focused continuously so that every student has a good awareness so that they use this well. Pamulang University should be the organizer of e-learning. Because now many applications make it easier for everyone to access learning, Pamulang University should change the e-learning system that was originally web-based to application-based or android e-learning. The goal is to facilitate students and lecturers in accessing when learning is done online.

\section{Acknowledgement}

The authors would like to thanks to the people who have been instrumental in their assistance and the successful completion of this study.

\section{Author's Contributions}

All authors discussed the results and contributed to from the start to final manuscript. 


\section{Conflict of Interest}

The authors declare that they have no competing interests.

\section{References}

AECT. (1997). Educational technology: definition and glossary of terms. (Vol. 1). Washington DC.

Almanshur, G. d. (2012). Qualitative Research Methods. Yogyakarta: Ar-Ruzz Media.

B. One cheat. (2007). Initiatives in Improving Education Quality. Journal of Education and Culture, p. 602

B. H. Khan. (2005). Managing E-Learning: Design, Delivery, Implementation, and Evaluation. USA: Idea Group Inc.

D. Generous. (2014). Development of E-learning Theory and Design. Bandung: PT Youth Rosdakrya

Hartati. (2017). Analysis of E-learning Implementation System Using the UATAUT Method. Journal of Global Informatics, 8 (1), 13-18.

Gartika, E., Rahayu, W., \& Utomo, E. (2019). Development of Interactive Mathematics Multimedia Teaching Materials for Building Space in Class V Primary Schools. International Journal for Educational and Vocational Studies, 1(5), 467-472.

Irfansyah, J., Ekohariadi, E., \& Buditjahjanto, A. (2020). The Effect of Using Augmented Reality Media in Learning Achievement Especially Psychomotor Domain at Computer Assembling Subject of $X$ Multimedia Students in SMKN 10 Surabaya. International Journal for Educational and Vocational Studies, 2(4).

Kimmel, H., \& Deek, F. E. (1995). Instructional technology: A tool or a panacea?. Journal of Science Education and Technology, 4(4), 327-332.

Mutmainnah, T., Munoto, M., Marniati, M., \& Rijanto, T. (2020). Application of It-Based Learning Media to Improve the Basic Skills of Sewing Technology. International Journal for Educational and Vocational Studies, 2(3).

Molinda, M. (2005). Instructional Technology and Media for Learning New Jersey Colombus.

Purwanita, Y., Riyanto, Y., \& Suyanto, T. (2019). The Influence of Multimedia Assisted Inquiry Learning Methods on My Heroes' Theme of Critical Thinking Skills and Learning Outcomes of Class IV Students of Elementary School. International Journal for Educational and Vocational Studies, 1(2), 75-80.

Sukamadinata, N. S. (2002). Educational Research Methodology. Bandung: Teen Rosdakarya.

Setyosari. (n.d.). Retrieved July 14, 2020, from https://media.neliti.com/media/publications/220215learning-system-online-challenge-and.pdf

Sukamadinata, N. S. (2002). Educational Research Methodology. Bandung: Teen Rosdakarya.

Sukariasih, L., Erniwati, E., \& Salim, A. (2019). Development of Interactive Multimedia on Science Learning Based Adobe Flash CS6. International Journal for Educational and Vocational Studies, 1(4), 322-329.

Thomas, T. (2017). Teaching is an Art: Maximize Your Teaching. Yogyakarta: CV Budi Utama.

Warsita, (2013). Development of the Definition of the Learning Technology Area and Its Role in Solving Learning Problems Vol. December 1, 2013

Walgito. (2004). Guidance and Counseling in Schools. Yogyakarta: Andi.

Widodo, J. (2019). President-joko-widodo-at-inauguration-opening-indonesia-industrial-summit-2018-andlaunch-making-indonesia-4-0-4-april-2018-in-jakarta-convention -center-jcc-senay. 